Tropical Journal of Applied Natural Sciences
Trop. J. Appl. Nat. Sci., 2(1): 6-10(2017)
ISSN: 2449-2043
https://doi.org/10.25240/TJANS.2017.2.1.02

\title{
Studies on the Plasma Albumin and Globulin Contents of the African Catfish (Heterobranchus bidorsalis) Adult Injected with Graded Concentrations of Bonny-Light Crude Oil
}

\author{
Arazu, V.N. ${ }^{1}$, Ikwor, T.N. ${ }^{2}$, Nwosu, M.C.*1 ${ }^{1}$ Ugwu, L.L. ${ }^{2}$ and Ibemenuga K.N. ${ }^{1}$ \\ ${ }^{1}$ Department of Biological Sciences, Chukwuemeka Odumegwu Ojukwu University, Anambra State, Nigeria \\ ${ }^{2}$ Department of Fisheries and Aquaculture, Ebonyi State University, P.M.B. 052, Abakaliki, Nigeria.
}

*Corresponding author’s email: chukellisnwosu@yahoo.com

\begin{abstract}
The plasma albumin (ALB) and globulin (GLB) concentration of the plasma of Heterobranchus bidorsalis adults (mean weight, $138.32 \pm 0.36 \mathrm{~g}$ ) injected with graded concentrations of Bonny-light crude oil (BLCO) were studied. Two study periods viz: the toxicity (4 days) and the recovery (42 days) periods were adopted. Significant increases $(\mathrm{P}<0.05)$ in the ALB content $(\mathrm{mg} / 100 \mathrm{ml})$ of the plasma were recorded with fish injected with $10.00-50.00$ microlitre per gram $\left(\mu 1 . \mathrm{g}^{-1}\right)$ BLCO. Conversely, significant decreases $(\mathrm{P}<0.05)$ in the GLB content $(\mathrm{mg} / 100 \mathrm{ml})$ of the plasma were also recorded. These results implied that increases in BLCO concentrations within the fish might have impacted for both ALB and GLB on the synthesis of these globular proteins and by extension on protein turn over in the Plasma. The $50.00 \mu 1 . \mathrm{g}^{-1} \mathrm{BLCO}$ concentration in the fish gave the highest value of ALB, during both study period. The $10.00 \mu 1 . \mathrm{g}^{-1} \mathrm{BLCO}$ concentration recorded the least values of GLB in the fish. This result also suggested that negative responses of ALB and GLB proteins to the presence of the crude oil compound were utmost at these BLCO concentrations. However, increases in ALB and GLB values during the recovery period attested to the apparent relief of the fish from the toxic and lethal effects of the oil pollutant. Fish mortality recorded within both study periods is consistent with the report of other workers that pollutants induced stress and perturbations in the functional integrity of the physiological processes in fishes, culminating in mortality.
\end{abstract}

Original Research Article

Received: 10th Aug., 2017. Accepted: 12th Oct., 2017. Published: 23 ${ }^{\text {rd }}$ Oct., 2017.

Keywords: African Catfish; Heterobranchus bidorsalis, Albumin;

Globulin;

Hydrocarbon.

\section{INTRODUCTION}

$\mathrm{T}$ he low survival rates of the giant African catfish (Heterobranchus bidorsalis, Geoffroy St. Hiliare, 1809) juveniles in the Nigeria Aquaculture system is a disturbing phenomenon. Part of the reasons for the low survivals include cannibalism (Ugwu et al., 2006), nutritional problem (Faturoti et al., 1986; Nwosu et al., 2009, Okeke et al., 2016; Okeke et al., 2016 and Nwosu, 2017) and the environment (Ozmen et al., 2005). Freshwater fish are used as 96 - hour bioassay test organisms (Kopperdaul, 1976) for the determination of crude oil toxicity. Many workers (Stobber et al., 1978; Cardwell, 1979) have reported on the toxicity resulting from oil spills that occurred in aquatic environments near big oil industries, and stated that fish larvae, fingerling and eggs are quite sensitive bioassay test organisms $H$. bidorsalis in the Nigeria waters is a highly esteemed hardy fish due to the possession of accessory air- breathing organs which, enable it tolerate diverse aquatic conditions (Reed et al., 1967). H. bidorsalis adults and juveniles nevertheless may be very sensitive to aquatic pollutants including crude oil and its products.

The effect of xenobiotic contamination in an aquatic ecosystem can be estimated through analysis of biochemical changes in the organisms inhabiting that region (Tuvikene et al., 1996; Norris et al., 2001; Brewer et al., 2001). Some deleterious effects of exposing fish species to crude oil have been determined to include: alteration of the immune response mechanisms, changes in liver metabolism, haemorrhage and even death (Neff and Anderson, 1981). The aquatic ecosystem, like the terrestrial environment, is continuously subjected to changes in quality following the introduction of substances of diverse characteristic arising from man's cultural activities (Oluah, 2001). This author stated that alteration in water quality usually predispose the 
fish to stress and disease, and elicit quick responses in the physiology of the fish, especially the haematological parameters.

The need to determine the effect of crude oil infiltration into the blood stream of fish species has been expressed and the procedure of bio-chemical analyses has been elected as the best option (Tuvikene et al., 1996). It has also been suggested that the uptake and translocation of crude oil compounds in fish may be through the gills, the gut and the intestinal walls (Roubal et al., 1977). The parent compounds of crude oil were found to solubilize in the cell membranes and were carried via the erythrocytes to the general circulation of the blood. However, the specific individual metabolites that result from the uptake and metabolic conversion of petroleum aromatic compounds (ACs) (Oriji and Zakka, 2014). In fish have not been well characterized (Khan et al., 1992 \& 1995; Origi and Zakka, 2014). Crude oil exposures of adult marine fish species have been reported to increase the mortality rate and changes in the haemoglobin content of blood (Tatem et al., 1979).

The damage done to the physiological processes in fish by crude oil compounds is likely to commence in the blood. Since the translocation of crude oil compounds goes via the erythrocytes to the general circulation of the blood (Roubal et al., 1977), the tendency that the blood components would be depleted is certain. The albumin and globulin components of the plasma are globular proteins that occur in the blood of animals, including fish (McDonald et al., 1995). These protein especially the albumin, are water soluble and heatcoagulable and therefore could be adversely affected by crude oil compounds. Against this background, this study was designed to investigate the effect of injecting $H$. bidorsalis adults with graded concentrations of Bonny-light crude oil (BLCO) on the albumin and globulin contents of the blood. The essence was to ascertain the degree of physiological damage done to these fish blood proteins consequent upon the infiltration of crude oil compounds into the general circulation of the blood.

\section{MATERIALS AND METHODS}

Eighteen (18) plastic containers (25-litres capacity) were randomly stocked with 360 adults of $H$ bidorsalis [mean weight \pm standard error of mean (s.e.m), $138.22 \pm 0.36 \mathrm{~g}]$ at 20 fish per container. The experiment was designed to have 18 plastic containers ( 6 groups each having 3 containers) with 15 litres dechlorinated tap water and fish. The fish were injected with graded concentrations of BLCO at 10.00, 20.00, $30.00,40.00$, and $50.00 \mu \mathrm{lg}^{-1}$. Three (3) containers had fish not injected with crude oil served as the controls $\left(0.00 \mu \mathrm{lg}^{-1}\right)$. The injection of fish was done with $2.50 \mathrm{ml}$ disposable hydrodermic syringes, just below the dorsal fin.

Two study periods were adopted for the research viz: the toxicity and the recovery periods. Four (4) days was adopted as the toxicity period of the injected BLCO concentration in the fish since freshwater fish are used as 96 - hours bioassay test organisms for the determination of crude oil toxicity (Kopperdaul, 1976). The recovery period lasted for 42days and was monitored fortnightly (14 days interval). At the end of the toxicity period, the surviving fish and plastic containers were washed and replenished with 15 litres dechlorinated tap water. A previously formulated fish diet (38\% crude protein) (Table 2) was fed to the fish at $5 \%$ body weight per day (bwd1) during the toxicity period and at $5 \%$ bw.d-1 during the recovery period. The proximate composition of the diet (Table 3) was carried out as described by AOAC (1990).

Records of the water temperature $\left(27 \pm 0.12^{\circ} \mathrm{C}\right)$ and $\mathrm{pH}(6.76$ $=\mathrm{t} 0.4$ ) were taken with the aid of a maximum and minimum mercury-in-glass thermometer and a pH meter (Model pH-L 201-L) respectively. The percent mortality (PM) and the percent survival (PS) of the fish were estimated during the toxicity and recovery periods of the study. Blood samples of each triplicate treatment of BLCO and the control were collected during each study period. Ethylenediaminetetraacetic acid (EDTA) fluid was used to condition the syringes, needles and microfuge tubes before blood collection. Analysis of the albumin and. globulin protein of the blood was carried out within 12 hours at Bronilla Diagnostic Laboratory, Abakpa Nike, Enugu, Nigeria. Here, the blood was centrifuged for 15 minutes at 1000rpm to obtain the plasma.

The albumin content of the blood was determined by the addition of $3.30 \mathrm{ml}$ disodium tetraoxosulphate $\left(\mathrm{Na}_{2} \mathrm{SO}_{4}\right)$ to $0.40 \mathrm{ml}$ blood serum in a centrifuge tube with stopper. The serum and reagent were thoroughly mixed by inversion. $3.00 \mathrm{ml}$ of this mixture was transferred to a microfuge tube and further mixed with $1.00 \mathrm{ml}$ of ether analar. This was also mixed by inverting the tube 40 times. The tube was capped and centrifuged for 15 minutes at $1000 \mathrm{rpm}$. The tube was then sloped in order to transfer $1.00 \mathrm{ml}$ of the lower clear aqueous phase to another tube marked A (Albumin). The upper portion of this mixture was introduced into another tube marked $G$ (Globulin). This constituted the globulin component of the blood serum. Globulin is normally separated by disodium tetraoxo sulphate and is estimated by difference. For the blank test, $1.00 \mathrm{ml}$ of $\mathrm{Na}_{2} \mathrm{SO}_{4}$ was placed in a $300 \mathrm{ml}$ tube and marked B (Blank).

To each tube $\mathrm{A}$ and $\mathrm{B}, 4.00 \mathrm{ml}$ of biuret reagent comprising: $45.00 \mathrm{~g}$ Rochelle salt, $2 \mathrm{~N} \mathrm{NaOH}$ and $15.00 \mathrm{~g} \mathrm{CuSO}_{4}$ were introduced, mixed thoroughly, and allowed to stand for 30 minutes at room temperature. The final mixtures in tubes $\mathrm{A}$ and B were read in a colorimeter at 540 nanometer $(\mathrm{nm})$. The protein standard assay of the blood serum was carried out without the biuret reagent and this was also read in a colorimeter at $540 \mathrm{~nm}$. The colour produced by the serum albumin protein with the biuret reagent was estimated and compared with the protein solution of known strength. Estimation of the serum albumin in each triplicate sample was carried out as follows:

$\frac{\text { gAlbumin }}{100 m l}=\frac{\text { Albumin value }}{\text { Standard value }} \times \frac{\text { Concentration of standard }}{1}$

Where: the Albumin value was the colorimeter reading when the blood serum, $\mathrm{Na}_{2} \mathrm{SO}_{4}$ biuret reagent and ether analar were used. While the standard value was when the blood serum, $\mathrm{Na}_{2} \mathrm{SO}_{4}$ and distilled water (as blank) were used.

The statistical Programme was SPSS. All the data obtained were subjected to Analysis of Variance (ANOVA), least significant difference (LSD) and testing at $1 \%$ and 5\% level 
of significance to determine statistical differences between treatment means (Steel and Torrie, 1990). The simple percentages were also used to explain the analyzed data where appropriate.

\section{RESULTS AND DISCUSSION}

The physio-chemical properties of Bonny-light crude oil are present in Table 1. The gross and proximate compositions of the experimental diet fed to $H$. bidorsalis adults during the study period are shown in Tables 2 and 3 respectively. Tables 4 and 5 show the albumin (ALB) and globulin (GLB) contents of the blood respectively for fish injected with 10.00 - 50.00 $\mu \mathrm{lg}^{-1}$ BLCO and the control $\left(0.00 \mu \mathrm{l} . \mathrm{g}^{-1}\right)$. Table 6 shows the percentage mortality and survival of the fish.

The control fish recorded significantly $(\mathrm{P}<0.01)$ higher values of ALB in the blood than in those injected with the different BLCO concentrations (Table 4). This situation was prevalent both at the toxicity and the recovery periods of the study. ALB values also increased significantly $(\mathrm{P}<0.05)$ with increasing BLCO concentration in the fish during both study periods (Table 2). The recovery period of the fish (14 - 42 days) provided comparatively higher values of ALB in fish than what were obtained during the toxicity period, Generally, improvements in ALB values during the recovery period indicated that ALB Values increased by $5 \%$ at day 14 , $10 \%$ at day 28 and $18 \%$ at day 42 . Nevertheless, the highest ALB value $(5.32 \pm 0.03 \mathrm{mg} / 100 \mathrm{ml})$ recorded on day 42 with the fish recovering from $50.00 \mathrm{ul}^{-\mathrm{g}^{-1}}$ BLCO injection was lower than the corresponding ALB value of the control fish $(5.99 \pm 0.03 \mathrm{mg} / 100 \mathrm{ml})($ Table 4$)$.

The result of the globulin content of fish blood recorded in this study was apparently at variance with the values recorded for the albumin content. Whereas the ALB values increased with increasing BLCO concentrations, the globulin (GLB) values decreased (Table 5). Significant decreases $(\mathrm{P}<0.05)$ in GLB values were therefore recorded and the range values of GLB in the control fish $(2.53 \pm 0.04-3.46 \pm 0.04 \mathrm{mg} / 100 \mathrm{ml})$ were higher than those injected with BLCO concentrations (Table 5). Improvements in the values of GBL in the fish blood followed the pattern shown by the ALB values. Hence, as the recovery period extended from days 14 and 28 to day 42 the GLB values increased by 5, 10 and $18 \%$ respectively.

The percent mortality and survival of the fish (Table 6) indicated that those injected with $40.00 \mu \mathrm{l.g}^{-1}$ and $50.00 \mu \mathrm{l.g}$ ${ }^{1}$ BLCO recorded the highest fish mortality and the lowest fish survivals. In contrast, those injected with $10.00 \mu{\mathrm{l} . \mathrm{g}^{-1}}^{-1}$
BLCO recorded the least percent mortality and the highest percent survival (Table 6).

Improvements in the values of albumin (ALB) and globulin (GLB) contents of the blood serum of $H$. bidorsalis adults during the recovery period of this study implied that the toxic effects of the injected BLCO was being reduced with time. It could be that the percent increases in ALB and GLB values at day $14(5 \%)$, day $28(10 \%)$ and day $42(18 \%)$ were evidences of improved enzymatic synthesis due to protein accretion. Kaushik et al. (1995) reported that protein in the diet has an obligatory role of replacing lost body proteins as well as losses due to amino acid oxidation and utilization, for purposes other than protein synthesis and protein turn over. The improved feeding rate of the fishes during the recovery period must have provided the required amino acids for the synthesis of the lost globulins and albumins during the toxicity period.

The lower ALB values recorded in the injected fish at day 42 relative to the control implied that improvement in ALB values starting from day 14 up to day 42 did not guarantee any complete recovery of the fish from the toxic effect of BLCO. This result is consistent with the report of Khan et al. (1995), who recorded absorbed hydrocarbons (HCs) in minnows after 14 days of their transfer to uncontaminated sea water. Kennicutt and Sweet (1992) also detected spill-related contamination in intertidal limpet, Nacella concinna two years after the release of crude oil into Arthur Harbour in Antarctic Peninsulja. It is deduced from this work that the low values of ALB in the fish blood relative to the control must be due to the deleterious effects caused by the presence of BLCO in the blood stream of the fish.

The decreasing GLB values due to the increasing BLCO concentration in the fish agrees with the report of Olua and Njoku (2001). The workers posited that the exposure of fishes to even sublethal concentrations of pollutants induces stress and perturbations in the functional integrity of their physiological processes. The exposure of life forms (including fish) to hazardous chemicals (e.g. pesticides, crude oil and agro-chemicals) causes cell injury and death of even non-target organisms (Sotheiton, 1991; Moreby et al., 2001). The high fish mortality and low fish survival recorded with fish injected with $4.00-50.00 \mu \mathrm{l.g}^{-1}$ BLCO are consistent with the observations of the above authors and attest to the lethal effects of the oil pollutants on the fish. The percent mortality of the fish nonetheless decreased with low concentrations of the injected BLCO.

Table 1: Physico-chemical properties of Niger Delta crude oil

\begin{tabular}{llllllllll}
\hline Crude oil brand & $\begin{array}{l}\text { Specific } \\
\text { gravity }\end{array}$ & API & Viscosity & $\begin{array}{l}\text { Sulfur } \\
\text { content }\end{array}$ & $\begin{array}{l}\text { Pour } \\
\text { point }\end{array}$ & $\begin{array}{l}\text { Wax } \\
\text { cont. }\end{array}$ & $\begin{array}{l}\text { Asph } \\
\text { vol. })\end{array}$ & Acidity \\
\hline Bonny light & 0.8 & 8.4 & 4.09 & 0.14 & 23 & 3.8 & 0.05 & 0.65 \\
Bonny medium & 0.9 & 9 & 16.44 & 0.28 & 28 & 2.1 & 0.29 & 0.44 \\
Faroados Blend & 0.087 & 8.7 & 5.4 & 0.2 & 24 & 4.1 & 0.32 & 0.21 & \\
Excravos Blend & 0.77 & 7.7 & 3.67 & 0.12 & 25 & 5.3 & 0.14 & 0.67 & \\
Brass Blend & 0.75 & 0.75 & 2.24 & 0.1 & 20 & 6.8 & 0.14 & 0.45 & \\
\hline
\end{tabular}

Source: Oriji and Zakka (2014). 
Table 2: Gross Composition of Experiment Diet

\begin{tabular}{ll}
\hline Ingredient & \% composition \\
\hline Yellow maize & 9.29 \\
Soyabean meal & 54.84 \\
Fishmeal & 16.65 \\
Blood meal & 10.97 \\
Palm oil & 5.00 \\
Salt & 0.25 \\
Vitamin mix & 0.60 \\
Mineral mix & 2 \\
Total & 2.40 \\
\hline
\end{tabular}

Table 3: Proximate Composition of Experimental Diets

${ }^{1}$ Vitamin mix provided the following constituents diluted in cellulose $(\mathrm{mg} / \mathrm{kg}$ of diet): thiamin, 10. riboflavin, acid, 40; choline chloride, 3000; niacin, 150; vitamin $\mathrm{Bi} 2$, 0.06; retinyl acetate $(500,000 \mathrm{IU} / \mathrm{g}), 6$; menadione-Na-bisulphate, 80; inositol, 400; biotin, 2; vitamin C, 200; alpha tocopherol, 50; cholecalcipherol (1000,000 IU/g).

${ }^{2}$ Contained as g/kg of premix: $\left.\mathrm{FeSO}_{4} .7 \mathrm{H}_{2} \mathrm{O}\right), 5 ; \mathrm{MgSO}_{4} .7 \mathrm{H}_{2} \mathrm{O}, 132 ; \mathrm{K}_{2} \mathrm{SO}_{4}$, $329.90 ; \mathrm{Kl}, 0.15 ; \mathrm{MnSO}_{4} \cdot \mathrm{H}_{2} \mathrm{O}, 0.7$; and cellulose, 380. 97.

\begin{tabular}{ll}
\hline Ingredient & \% composition \\
\hline Crude protein & 37.58 \\
Ether extract & 5.18 \\
Ash & 10.48 \\
Dry matter & 11.80 \\
Nitrogen free extract & 36.46 \\
Total & 100.00 \\
\hline
\end{tabular}

Table 4: Albumin Content (mg/100ml) of the Blood of H. bidorsalis Adults Injected with Different Concentration of BonnyLight Crude Oil

\begin{tabular}{|c|c|c|c|c|c|c|c|c|}
\hline \multirow[t]{2}{*}{ Study period } & \multirow{2}{*}{$\begin{array}{l}\text { Duration } \\
\text { (days) }\end{array}$} & \multicolumn{5}{|c|}{$\mathrm{BLCO}^{1}$ Concentration $\left(\mu 1 . \mathrm{g}^{-1}\right)$} & \multirow{2}{*}{$\begin{array}{l}\text { Control } \\
0.00\end{array}$} & \multirow{2}{*}{$\begin{array}{l}\text { Overall } \\
\text { mean } \bar{x}\end{array}$} \\
\hline & & 10.00 & 20.00 & 30.00 & 40.00 & 50.00 & & \\
\hline Toxicity period & 4 & $1.26 \pm 0.02^{\mathrm{a}}$ & $1.51 \pm 0.02^{\mathrm{a}}$ & $2.71 \pm 0.04^{b}$ & $3.25 \pm 0.03^{\mathrm{c}}$ & $3.90 \pm 0.04^{c}$ & $4.40 \pm 0.03^{\mathrm{d}}$ & $2.84 \pm 0.02$ \\
\hline \multirow[t]{3}{*}{ Recovery period } & 14 & $1.32 \pm 0.01^{\mathrm{a}}$ & $1.59 \pm 0.02^{\mathrm{a}}$ & $2.85 \pm 0.02^{\mathrm{b}}$ & $3.39 \pm 0.04^{\mathrm{c}}$ & $4.10 \pm 0.04^{\mathrm{d}}$ & $4.62 \pm 0.02^{\mathrm{d}}$ & $2.98 \pm 0.03$ \\
\hline & 28 & $1.45 \pm 0.03^{\mathrm{a}}$ & $1.75 \pm 0.03^{\mathrm{a}}$ & $3.14 \pm 0.02^{\mathrm{b}}$ & $3.73 \pm 0.03^{b}$ & $4.51 \pm 0.03^{c}$ & $5.08 \pm 0.04^{\mathrm{d}}$ & $3.28 \pm 0.03$ \\
\hline & 42 & $1.71 \pm 0.01^{\mathrm{a}}$ & $2.07 \pm 0.02^{\mathrm{b}}$ & $3.71 \pm 0.04^{\mathrm{c}}$ & $4.40 \pm 0.06^{\mathrm{d}}$ & $5.32 \pm 0.03^{\mathrm{e}}$ & $5.99 \pm 0.03^{\mathrm{e}}$ & $3.53 \pm 0.04$ \\
\hline
\end{tabular}

Values in the same row with similar superscripts are not significantly different $(\mathrm{p}>0.05)$.

Table 5: Globulin Content (mg/100ml) of the blood of H. bidorsalis Adults Injected with Different Concentration of BonnyLight Crude Oil

\begin{tabular}{|c|c|c|c|c|c|c|c|c|}
\hline \multirow[t]{2}{*}{ Study period } & \multirow{2}{*}{$\begin{array}{l}\text { Duration } \\
\text { (days) }\end{array}$} & \multicolumn{5}{|c|}{ BLCO $^{1}$ Concentration $\left(\mu 1 . \mathrm{g}^{-1}\right)$} & \multirow[t]{2}{*}{ Control 0.00} & \multirow{2}{*}{$\begin{array}{l}\text { Overall } \\
\text { mean } \bar{x}\end{array}$} \\
\hline & & 10.00 & 20.00 & 30.00 & 40.00 & 50.00 & & \\
\hline Toxicity period & 4 & $0.63 \pm 0.02^{\mathrm{a}}$ & $0.41 \pm 0.01^{\mathrm{a}}$ & $0.27 \pm 0.01^{\mathrm{b}}$ & $0.18 \pm 0.01^{\mathrm{c}}$ & $0.01 \pm 0.00^{\mathrm{d}}$ & $2.53 \pm 0.04^{\mathrm{e}}$ & $0.67 \pm 0.01$ \\
\hline \multirow[t]{3}{*}{ Recovery period } & 14 & $0.66 \pm 0.02^{\mathrm{a}}$ & $0.43 \pm 0.02^{\mathrm{a}}$ & $0.28 \pm 0.02^{b}$ & $0.10 \pm 0.01^{\mathrm{c}}$ & $0.01 \pm 0.00^{\mathrm{d}}$ & $2.66 \pm 0.03^{\mathrm{e}}$ & $0.71 \pm 0.02$ \\
\hline & 28 & $0.73 \pm 0.02^{\mathrm{a}}$ & $0.47 \pm 0.01^{\mathrm{a}}$ & $0.31 \pm 0.01^{\mathrm{b}}$ & $0.21 \pm 0.01^{\mathrm{c}}$ & $0.01 \pm 0.00^{\mathrm{d}}$ & $2.93 \pm 0.03^{\mathrm{e}}$ & $0.78 \pm 0.01$ \\
\hline & 42 & $0.86 \pm 0.03^{\mathrm{a}}$ & $0.47 \pm 0.01^{b}$ & $0.37 \pm 0.02^{\mathrm{c}}$ & $0.25 \pm 0.01^{\mathrm{d}}$ & $0.01 \pm 0.00^{\mathrm{e}}$ & $3.46 \pm 0.04^{\mathrm{f}}$ & $0.90 \pm 0.02$ \\
\hline
\end{tabular}

Values in the same row with similar superscripts are not significantly different ( $>0.05)$.

Table 6: Percent Mortality and Percent Survival of H. bidorsalis Adults Injected with Different Concentration of Bonny-Light Crude Oil

\begin{tabular}{|c|c|c|c|c|c|c|c|c|c|c|c|c|c|}
\hline \multirow{3}{*}{ Study period } & \multirow{3}{*}{$\begin{array}{l}\text { Duration } \\
\text { (days) }\end{array}$} & \multicolumn{6}{|c|}{$\%$ Mortality } & & & & & & \\
\hline & & \multicolumn{5}{|c|}{$\mathrm{BLCO}^{1}$ Concentration $\left(\mu 1 . \mathrm{g}^{-1}\right)$} & \multirow{2}{*}{$\begin{array}{l}\text { Control } \\
0.00\end{array}$} & \multicolumn{5}{|c|}{ BLCO $^{1}$ Concentration $\left(\mu 1 . g^{-1}\right)$} & \multirow{2}{*}{$\begin{array}{l}\text { Control } \\
0.00\end{array}$} \\
\hline & & 10.00 & 20.00 & 30.00 & 40.00 & 50.00 & & 10.00 & 20.00 & 30.00 & 40.00 & 50.00 & \\
\hline Toxicity period & 4 & 2.00 & 5.00 & 5.00 & 40.00 & 50.00 & 0.00 & 98.00 & 95.00 & 95.00 & 60.00 & 50.00 & 100.00 \\
\hline \multirow[t]{3}{*}{ Recovery period } & 14 & 2.00 & 3.00 & 4.00 & 32.00 & 40.00 & 0.00 & 98.00 & 97.00 & 96.00 & 68.00 & 60.00 & 100.00 \\
\hline & 28 & 1.00 & 2.00 & 2.00 & 36.00 & 36.00 & 0.00 & 99.00 & 98.00 & 98.00 & 76.00 & 64.00 & 100.00 \\
\hline & 42 & 0.00 & 1.00 & 16.0 & 26.00 & 26.00 & 0.00 & 100.00 & 99.00 & 99.00 & 84.00 & 74.00 & 100.00 \\
\hline
\end{tabular}

\section{REFERENCES}

AOAC (1990). Official Method of Analysis of Association of Official Analytical Chemist International (A.O.A.C). 16th edition, Vol. 1Gaitherburg, Maryland, U.S.A.

Brewer, S.K., Little, E.E., Delonay, A.J., Bevais, S.L., Jones, S.B. and Ellersieck, M.R. (2001). Behavioural dysfunctions correlate to altered physiology in rainbow trout (Oncohynchus mykiss) exposed to cholinesteraseinhibiting chemicals. Archives of Environmental Contamination and Toxicology, 40: 70-76.

Cardwell, R.O. (1979). Toxic substances and water quality effect of larva aquatic organisms. Washington Department of Fishery Technical Paper No. 45, 79 Pp.
Faturoti, E.O., Balogun, A.M. and Ugwu, L.L.C. (1986). Nutrition utilization and growth responses of Africa catfish (Clarias lazera) for different dietary protein levels. Nigeria. Journal of Applied Fisheries and Hydrobiology, 1: 41-45.

Kaushik, S.J., Doudet, T., Medole, F., Agurrie, P. and Blank, D. (1995). Protien and energy needs for maintenance growth. Bulletin of Japanese Society of Science and Fisheries, 35:985-989.

Kennicutt, M.C., and Sweet, S.T. (1992). Hydrocarbon contamination on the Antarctic Peninsula III. The Bahia Parniso, two years after the Spill. Marine Pollution Bulletin 25 (9-12): 303-306. 
Khan, M.N., Burrows, D.G, Ylitalo, G.M., Brown, D.W., Wigren, C.A., Collier, Toko, Chan, S. and Varanasi, U. (1992). Mass spectrometric analysis for aromatic compounds in bile offish samples after the Exxon Valdez Oil spill. Environmental Science and Technology 26: 116-126.

Khan, M.O.Q., Al-Gais, S.M. and Al-Marri, S. (1995). Petroleum hydrocarbon from fish from the Arabian Gulf. Archives of Environmental Contamination and Toxicology, 29(4):517-522.

Kopperdaul, F.R. (1976). Guidelines for performing static acute toxicity fish bioassays in municipal and industrial waste waters. California State Water Resources Control Board Report. $55 \mathrm{Pp}$

McDonald, P., Edwards, R. A. and Greenhalgh, J. F. D. (1995). Animal Nutrition 5th Edition, Longmans, London, Singapore $605 \mathrm{Pp}$.

Moreby, S. J., Southway, S., Barker, A. and Holland, J. M. (2001). A comparism of the effect of new and established insecticides on non-target invertebrates of winter wheat fields. Environmental Toxicology and Chemistry 20: $2243-2254$ https://doi.org/10.1002/etc.5620201017.

Neff, J.M. and Anderson, J.W. (1981). Response of marine animals to petroleum and specific petrol hydrocarbon. In; Applied Science, London Pp 58 - 66.

Norris, D.O., Camp, J.M., Maldonado, T.A. and Woodling, J.D. (2001). Some aspects of hepatic function in feral brount trout, Salmo trutta, living in maul contaminated water. Comparative Biochemistry and Physiology 127: 71 - 78.

Nwosu, M.C. (2017). Studies on the physico-chemical parameters and Plankton abundance in relation to fish productivity in four natural lakes in Anambra State, Southeastern Nigeria. Journal of Innovative Science and Research, 2(8): $365-373$.

Nwosu, M.C., Nsofor, C.I., Okeke, J.J. and Anaeto, F.C. (2009). A valuation of the economic benefits and yield characteristics of a reference feed substituted with catfish (Heterobranchus bidorsalis) culture. Natural and Applied Science Journal 10(1): 83-89.

Okeke, J.J., Otikpa, C.I., Okeke, P.A., Ezeonyejiaku, D.C. Okoye, C.O., Arazu, V.N., Ibemenuga, K.N. and Nwosu, M.C. (2016). A comparative study of the effect of feeding frequency on growth and feed utilization of Clarias gariepinus fed on the commercial feed coppens. Scholarly Journal of Agricultural Science 6(7): 216-220.

Okeke, P.A., Nwige, H.C., Nwosu, M.C. and Arazu, V.N. (2016). Comparative study of different starter feeds on growth and survival of Clarias gariepinus fingerlings. Journal of Aquatic Science, 31(2B) 443-454.
Oluah, N.S. (2001). The effect of sublethal cadmium on the haematology of freshwater fish, Clarias gariepinus (Pisces: Clariidae). Journal of Science of Agriculture, Food Technology and Environment 1: 15-18.

Oluah, N.S. and Njoku, A.O. (2001), Paraquat induced glucose flux in the catfish, Clarias gariepinus (Pisces: Clariidae). Journal of Science of Agriculture, Food Technology and Environment 18: 241-246.

Orji, A.B. and Zakka, S.B. (2014). Physio-chemical analysis of a typical crude oil spillage site in the Niger Delta. Reiko International Journal of Science and Technology. 5(2): $38-48$.

Ozmen, M., Gungordo, A., Kucukbay, F.Z. and Guler, R.E. (2005). Monitoring the effects of water pollution in Cyprinus carpio in Karakaya Dam Lake, Turkey. Ecotoxicology 45:157-169.

Reed, W., Burchard, J., Hopson, A. J., Jonathan, J. and Ibrahim, Y. (1967). Fish and Fisheries of Northern Nigeria. Govt. Press, London. 226 Pp.

Roubal, W.T., Collier, T.K. and Malins, D.C. (1977). Accumulation and Metabolism of Carbon - 14 labelled Benzene, Naphthalene and anthracene by young Coho Salmon (Oncorhynchus Kisutch). Archives of Environmental Contamination and Toxicology. 5: 515-529.

Sotherton, N.W. (1991). Construction headlands and practical combination of intensive cereal farming and conservation. Pages 373-397. In: Firbank L.G. Carter, N., Nerby-shire, J.F. and Potts, G.R. (Eds.). The Ecology of Temperate Cereal Fields. Blackwell Scientific Publishers, Oxford.

Steel, R.G. D. and Torrie, J.H. (1990). Principles and procedures of statistics. McGraw-Hill, New York, 451 pp.

Stobber, Q.L, Daniel, P.A., Wert, M.A. and Nakatani, R.E. (1978). Toxicity of West Point effluent to marine indicator organisms Part II. University of Washington, College of Fisheries, Final Report, Fri - Un - 7937.

Tatem, H.E., Cox, B.A. and Anderson, J.W. (1979). The toxicity of oils and petroleum hydrocarbons to marine fishes. East Coastal Marine Science 6: 365-374.

Tuvikene, A., Huuskonen, S., Roy, S. and Lindstrom Seppia, O. (1996). Biomonitoring of South Estonian waters by means of xenobiotic metabolism of rainbow trout (Oncorhynchus mykiss). Comparative Biochemistry and Physiology C. 114: 171-177. https://doi.org/10.1016/0742-8413(96)00036-9.

Ugwu, L.L.C., Mgbenka, B.O. and Asogwa, M.O. (2006). Grow apart syndrome in the African catfish, Clarias gariepinus (Pisces: Claridae). Ife Journal of Science, 9(1): 33-44.

\section{How to cite this article}

Arazu, V.N., Ikwor, T.N., Nwosu, M.C., Ugwu, L.L. and Ibemenuga K.N. (2017). Studies on the Plasma Albumin and Globulin Contents of the African Catfish (Heterobranchus bidorsalis) Adult Injected with Graded Concentrations of Bonny-Light Crude Oil. Tropical Journal of Applied Natural Sciences, 2(1): 6-10. Doi: https://doi.org/10.25240/TJANS.2017.2.1.02. 